AP: Ontine Journat in Public Archaeology Volume 6-2016 p. 27-50

\title{
Development and Re-Configuration of Heritage Perception: History Textbooks and Curriculum
}

\author{
Veysel APAYDIN \\ Institute of Archaeology, UCL
}

Received: 26/02/16 - Accepted: 15/08/16

\begin{abstract}
The plundering, looting and neglect of archaeological and heritage sites are quite common in many parts of the world. Turkey is one such country that has a poor record of preservation of archaeological and heritage sites, particularly those of minority ethnic groups and from the prehistoric and ancient periods. In other words, those which are not part of the national/official past of Turkey. The main reason for this is that Turkish formal education neglects the prehistoric and ancient past, and 'others' the past of minority groups. This paper will examine and discuss how and to what extent archaeology and heritage related topics are presented in formal education in Turkey, i.e., national, minority groups, prehistoric and ancient pasts and antiquities by analysing the curriculum and textbooks from 2013. Specifically, this paper will demonstrate that history education in schools has a major impact on the development and re-configuration of heritage perception, which can either lead to the protection or neglect of heritage.
\end{abstract}

\section{Key words}

Archaeology, Heritage, Education, Textbooks, History and Politics

\section{Introduction}

Every single person in society has a right to learn about his or her own past. This statement of people's educational rights was part of the universal human rights declaration in 1948. It reinforces the 
idea that learning about history should not be restricted and that everybody should have access to past. The 1972 UNESCO World Heritage Convention and the 2003 Safeguarding Intangible Cultural Heritage Convention increased the protection and preservation of past materials and set out certain criteria. UNESCO state that: 'member states should undertake educational campaigns to arouse widespread public interest in, and respect for the cultural and natural heritage. Continuing efforts should be made to inform the public about what is being and can be done to protect the cultural or natural heritage and to inculcate appreciation and respect for the values it enshrines. For this purpose all media of information should be employed as required' (UNESCO 1972: article 61).

The most significant way to teach the public about the past and increase awareness of heritage protection is through history and heritage textbooks used in formal education, which help to form people's heritage perceptions. Therefore, more attention should be paid to history and heritage textbooks and they should be designed according to the criteria set out by UNESCO. Furthermore, textbooks should cover all periods and cultures equally, as well as the importance of heritage protection. Turkey is a signatory of the Declaration and has increased the emphasis on cultural heritage in textbooks; however, this has been from an official and nationalist perspective, which aims to consolidate Turkish identity.

\section{Heritage, Archaeology and Education: The Role of Schooling}

Schools are powerful institutions because students attend them from a very early age to adulthood when their knowledge, personalities and characters are formed. Therefore, education is a very effective way to shape children's perceptions, children who later will be the adults who will have a role in shaping the future of their societies. The school not only controls individuals but it also controls 'meaning' and 'legitimate knowledge' (Apple 2009: 61), which are in turn controlled by the state.

In the context of archaeology and heritage, schools are also the most important places where children can obtain knowledge of the past and broaden their horizons in the role of heritage and 
the need for its protection. As Stone (1985) emphasises, the only way of reducing the destruction of heritage is by raising the level of awareness of the public, most importantly children, through education. However, in Turkey and many nation states, the statecontrolled and strictly centralized education system (Corbishley 2011) doesn't allow for democratic and free education. Therefore, the methods of teaching at schools and the contents of textbooks and curricula should be reconsidered and redesigned accordingly, with a more democratic approach to education.

Although teaching history, archaeology and heritage may offer beneficial elements for school children, there are still several issues with school textbooks and curricula (Kasvikis, Vella and Doughty 2007: 129). For instance, archaeology, heritage and the study of the past are often given less importance than other subjects, and teaching about the past is problematic in Turkey (Doughty 2007), the UK (see Copeland 2004; Henson 2004: 16-19), and many other nation states (Corbishley 2004: 69; see also Stone and Molyneaux 1994). The question is why learning about the past is given less importance than other subjects. Clearly, there is not just one but many answers to this question. The answers and the reasons may also vary from country to country.

In the case of Turkey, the main reason for not learning and teaching about the past is the nationalist view that aims to protect the state's national identity, believed to go back thousands of years in Turkey (Ersanlı 2003), through the neglect or manipulation of the histories of other ethnic groups and focusing more on the Turkish past (Apaydin 2015).

In contrast, the achievement of learning every stage of history, having ideas on different cultures' pasts and heritage would lead to the democratization of education in countries such as Turkey. Roord (2004: 22) points out that "the aim and objectives for school history are broadly the same everywhere in Europe. Almost everywhere we can find that history education is supposed to enhance citizenship, democracy and critical thinking skills and should help students to understand the world they live in." Therefore, students could develop critical thinking; reconnecting subjectivity and experience with knowledge. Having limited knowledge about archaeological 
30 - Veysel APAYDIN - Development and Re-Configuration of Heritage...

remains and other cultures' pasts and heritage does not help efforts in the protection and preservation of heritage sites; in fact, it increases the neglect and leads to more looting and destruction of archaeological heritage remains.

\section{Historical Overview of Heritage and Education in Turkey}

Education is an important tool for nation states to transmit their ideological concepts, which are usually constructed during the foundation period and which then become the official ideology of the state, passed to their citizens through schools. In the case of Turkey, schools played a major role in the formation of Turkish nationalism and the construction of the Turkish state in the early $20^{\text {th }}$ century onwards (see Kaplan 1999).

During the nation-building process, archaeology and heritage were also major means used for advancing Turkish identity. Particularly, archaeology and heritage were used intensively as tools within schooling, and were transformed into a nationalist concept that has been highly visible in the education system. The content of history textbooks, which contain cultural heritage and archaeological aspects, has approached history from a nationalist point of view since 1923, when the Republic of Turkey was officially declared. During this period, the history of Turkey was rewritten from a nationalist perspective (see Ersanlı 2003).

The relationship between nationalism and the writing of history can be seen in the history of any nation state during and after its construction. During the construction of the nation states, history offers a great opportunity for nationalists to construct the nation state on a solid basis, and to carry its future generations by creating a relationship between the past and present (Apaydin 2015). In order to be successful, nationalists adapt various myths to glorify their nation's history. However, often this relationship is constructed on a manipulation of history. Smith (1994: 18) emphasises the importance of history to nationalism: "for nationalists themselves, the role of the past is clear and unproblematic. The nation was always there, indeed it is part of the natural order, even when it was submerged in the hearts 
of its members. The task of the nationalist is simply to remind his or her compatriots of their glorious past, so that they can recreate and re-live those glories." History was significant in the case of the Turkish nation state. Atatürk, the founder of modern Turkey, clearly indicated the aim of rewriting Turkey's history, and pointed out that 'writing history is as important as creating history'.

The 1930s were a significant time in the writing of school history textbooks. The aim at the time was to rewrite and dignify Turkish history. The main reason, as Tarman points out (2008: 12), was to construct a new national identity. Rewriting the history led to the construction of a Turkish history that could support Turkish nationalism. To achieve this, the "Turkish History Congress" was organised in 1930s in order to rewrite and develop the Turkish history thesis. The Turkish History Congresses (particularly first congress in 1932) were quite significant because their results had a major impact on the construction of the official Turkish ideology (Atakuman 2008; Ersanlı 2003). It can also be seen from the Congresses that archaeology played a significant role in shaping the official ideology. However, the archaeology was highly manipulated and was used to glorify the Turks and Turkish history, while ignoring the many other cultural identities and histories of Anatolia.

The results of the Turkish History Congress were also reflected in history textbooks and can clearly be seen in the four volumes of the history textbooks that were prepared for high schools. The first volume of this series focused on the first civilizations and the first Turkish states in history (Günaltay 1939). In this book, it is argued that the history of the Turks dates back to 20,000 BC when Turks began to migrate from the 'Motherland' (central Asia) to other parts of the world. The inhabitants of central Asia were described as Hatti, Eti or Hittites. According to the book, these groups established an empire in central Asia, and then spread to other parts of the world by establishing small-scale kingdoms. For instance, it is stated that the same group of people arrived in Lebanon in 2800 BC, and then later established the Phoenician state and the Hittite Empire (see Günaltay 1939). The book mainly focused on the capability of the Turks by establishing their great and powerful states in history (Ersanlı 2003). 
During the congresses and writing of history textbooks the minorities of Turkey, such as Armenians, Greeks, Jews, etc., along with their histories and heritage, were completely neglected. The main reason for neglecting and manipulating the histories of minorities in Turkey was linked to ownership rights of the lands of Turkey.

In following decades, particularly from the second half of the $20^{\text {th }}$ century onwards, the main aim and focus of the history textbooks did not change much. The history textbooks have mostly focused on the main component of the Turkish identity, which includes early Turkish history, Islam, the Ottoman Empire as well as the history of modern Turkish Republic (see Guler-Biyikli and Aslan 2013), which also shapes the Turkish ideology and nationalism. The dominance of the nationalist view has shaped people's minds as well, which in turn affects the understanding of cultural heritage and the concept of archaeology in Turkey (see Apaydin 2015).

\section{Methodological Approach: Qualitative and quantitative data analysis}

The aim of this paper is to analyse and highlight the reasons for undeveloped heritage awareness that leads to the neglect of archaeological and heritage sites, through the examination of the 2013 primary and secondary school social sciences curricula and high school history textbooks. Specifically, this paper analyses to what extent and the ways history, archaeology and heritage related subjects are taught to students and, therefore, how the heritage perception of communities is formed through the schooling process.

I selected the $4^{\text {th }}, 5^{\text {th }}, 6^{\text {th }}, 7^{\text {th }}$ and $8^{\text {th }}$ levels of the social sciences' curricula (the social sciences curricula in primary and secondary education instruct teachers how, and to what extent, subjects are taught to students, alongside various approved textbooks) for analysis. These sections contain archaeological and historical materials for primary and secondary education (the age range is from 6 to 13/14 years old). Textbooks 9-10 and 11, which are general social science textbooks for high schools (age range from 13 to $17 / 18$ years old), were also analysed. Analyses of these materials were done in order to answer the following questions: 
To what extent is modern national Turkish identity/ethnicity being portrayed as having roots in Turkey's ancient past? To what extent do the Turkish, Islamic and Ottoman pasts appear in the curricula and textbooks? How do textbooks relate to ancient history with specific reference to modern-day Turkey? To what extent do textbooks discuss the histories of minority groups with specific reference to Turkey? To what extent do curricula and textbooks give importance to prehistoric and ancient periods and material culture?

I examined these aspects qualitatively and quantitatively. First, I applied critical discourse analysis to reveal hidden meanings in the texts and images. Critical discourse analysis is necessary "as language use in speech and writing is a form of social practice which implies a dialectical relationship between particular events and situations, institutions and social structures" (Fairclough and Wodak 1997: 258). Such writing is common in textbooks. Texts are often written with 'implicit prejudiced utterances by the writers who often use allusions' (Fairclough and Wodak 1997: 266), and these can be identified through critical discourse analyses. Second, I quantified the subjects according to themes. In the quantitative analysis, I categorised themes under certain subjects, for instance: the national/official past, including the Turkish, Islamic and Ottoman pasts; minority peoples' pasts; and the prehistoric and ancient pasts, and antiquities.

Following the textbooks analyses, I carried out semi-structured interviews with community members, who live near internationally significant sites, i.e., those which are listed as World Heritage Sites by UNESCO. These sites are Çatalhöyük, a Neolithic site, and Ani, which mainly dates to the Armenian Kingdom ( $10^{\text {th }}$ to $11^{\text {th }}$ centuries $A D)$. The aim of the interviews was to assess the impact of formal education on people's heritage perception, and therefore I asked questions regarding how they see and evaluate the past and heritage. Interview participants were selected randomly from the nearby villages. I paid much attention to select community members from ethnically, socially and politically different backgrounds. In the sections below, I will use excerpts from the interviews in addition to textbooks analyses. 
34 - Veysel APAYDIN - Development and Re-Configuration of Heritage...

\section{National/Official Past: Turkish, Islamic and Ottoman Heritage}

In Turkish formal education, history related subjects are taught in detail and the time given to them is quite substantial. However, the history is taught from an official historical perspective, upon which Turkish identity is constructed. The general sections of the curricula and textbooks from the $4^{\text {th }}$ to the $11^{\text {th }}$ levels are written by authors who are under strict control of the ministry, and so all texts reflect the Turkish official historical perspective. The general sections from the textbooks give the most importance to the history of the Republic of Turkey, particularly during the construction period in 1920s and 30s, the Ottoman past, the Islamic past and the Turkic past in central Asia.

The three elements, the Turkic culture in central Asia, Islam and the Ottoman Empire, were of utmost important during the construction of the Turkish nation state as well because these aspects were/are the main tenets of the official historical perspective of the modern Turkish state (Copeaux 1998a; Ersanlı 2003) and the identity of Turkish state.

All of the curricula instruct teachers to emphasise the importance of historical days, national days and religious days. For instance, the level 4 curricula dictate teachers to ask students the following:

... what do you do during national and religious days (public holidays)? ... By looking at the motifs of traditional ceramic tiles ... what is your understanding about Turkish art? Where can you see motifs similar to those on the ceiling of the Selimiye Mosque-built in the 16th century in Edirne? ... (Kaya-Koyuncu et al. 2013: 100-101).

The quote demonstrates a clear example of one of the ways that the teachers who are instructed and controlled by the national education ministry impose Islamic views onto children from an early age. The questions quoted above make strong links between Turkish history and Turkish culture, which includes the Turkic countries in west central Asia, the Ottoman Empire, Islam and the modern Turkish state. The Selimiye Mosque is directly linked with the Ottoman Empire as it is located in Edirne, which was once a 
capital, at the same time, Selimiye Mosque is also symbolically important for Islam; Turkish art references Turkic history in central Asia; and national and religious days are very important in the Turkish Republic today.

Similarly, the $6^{\text {th }}$ level curricula is mainly focused on the success and cultural life of the first Turkish states in central Asia as students are presented with the ancestors of the modern Turks (see Köstüklü 2013: 96). These connections between Turkish states in central Asia and the Republic of Turkey are often made in the textbooks in order to ensure that the pupils are aware that the roots of the Turks date back thousands of years. The connection between Central Asia and Anatolia is also related to other sections in the $6^{\text {th }}$ level curricula: 'From Motherland to Anatolia' (see Köstüklü 2013: 98).

During the 1930s, two congresses were organised in order to rewrite Turkish history. The main aim of the congresses was to present the Turks as the leading civilisation of humanity and who brought all inventions to other civilisations of the world. Furthermore, one could argue that the official history that was dominant in the 1930s history textbooks still continues in the modern day history curricula and textbooks. For example, the teacher is instructed to:

... present the map to students under the heading 'from the motherland to Anatolia' and emphasise that the Turks have moved and settled in many parts of the world ... (Köstüklü 2013: 98).

Another connection between early Turkish states and the modernday Turkish state is made under the heading: 'From Cavalier (horseman warriors) to the Modern Turkish Army' and strongly emphasises the connection between the first Turkish national army in Central Asia and the modern Turkish army (see Köstüklü 2013: 108). The army in central Asia is presented as the basis of the modern Turkish army and the text also indicates that the modern Turkish army was established in 209 BC, and then developed with the contribution of later Turkish states such as the Ottoman Empire and Republic of Turkey.

The emphasis on the connection between the first Turkish states and the modern day Turkish state indicates that Pan Turkism, which was popular during the first period of construction of Turkish nationalism 
and the Turkish nation state, is still present. The main arguments of Pan-Turkism were that all Turks should be united politically and geographically, and the main component of Pan-Turkism was the Turkish race, who were believed to have descended from the Turks in Central and West Asia, the 'motherland' (see Ersanlı 2003).

In almost all of the textbooks, one can clearly see that many embedded discourses make strong connections between Turks and Islam. For instance, the $6^{\text {th }}$ level of the history classes discusses the 'Birth of Islam and its Expansion' and 'the first Turkish Islamic States' (Köstüklü 2013: 114 and 120). The expansion of Islam all over the world, supported with maps and pictures, is discussed and teachers are instructed to emphasize the strong connection between beliefs of the Turks in central Asia and Islam. The text implies that this is the reason why the Turks accepted Islam, as it has a similarity to Turkish culture; it also implies that Islam was the most suitable religion for the Turks, as they could carry on their own unique cultural life. The text also points out that the conversion of the Turks was significant, because Turks then took Islam to other parts of the world (Köstüklü 2013: 119). This strong emphasis on the connection between Turks and Islam has existed since the Turkish Republic was established. Therefore, it is of no surprise that the current history curricula and texts give great importance to connecting Turks and Islam.

The $7^{\text {th }}$ level of the history classes also focuses on the history of Turks and the Turkification process of Anatolia by mainly focusing on the success of the Seljuk Empire and the Anatolian-Turkish Beyliks, and later the birth of the Ottoman Empire, its structure and success, the cultural attraction between Europe and the Ottomans, and the reforms that took place during the Empire. While the section of the texts mainly focuses on how Anatolia was retaken from the Byzantine Empire, the history and culture of the Byzantines are completely excluded from both illustrations and the texts of the books, despite the fact that the empire had over a thousand-year history in Turkey. Instead, the specific terms used form a discourse against the Byzantine. For instance, the text instructs:

... remind students how important the battle of Manzikert was [where Seljuk and the Byzantines fought a battle for 
the control of Anatolia in $1071 \mathrm{AD}]$... if it was lost against Byzantine we would not occupy these lands and the Islamic countries would be in great danger [would face danger because of the Byzantines] ... (Güven 2013: 113).

The themes provide, with perfect illustrations, explanations for the expansion of the Turks and the Ottomans. The $7^{\text {th }}$ level curricula also strongly emphasise the continued success of the Turks and their expansion from central Asia to Anatolia and then to Europe, supported also by maps and drawings.

The $8^{\text {th }}$ level history classes are completely reserved for the construction period of the Turkish nation state; Kemalist values; the tenets of Atatürk; the successes and victories of Atatürk against the coalition forces that aimed to invade Turkey at the end of the Ottoman Empire; and the life of Atatürk. All sections of the classes have strong implications of nationalism, instructing students on how they can be good Turkish citizens, how they can protect the state and support the development of the Turkish nation state by giving great importance to nationalistic values (see Başol et al. 2013).

The majority of the $9^{\text {th }}$ level history classes concerns the early Turkish states. The first theme of this chapter mostly focuses on the Turks in central Asia: How and why did they leave their homelands and how did they influence the cultures where they migrated to? Similar to early Turkish textbooks from the 1930s, the text also implies that Turks brought many inventions to the other cultures, as the text indicates:

... the Turks who left central Asia migrated to Anatolia, Syria, Central Europe and Siberia ... they established many states, then they influenced other cultures in terms of governance and military organization ... (Okur et al. 2013: 74).

Another theme of this chapter is the first Turkish states. For instance, the Hun Empire is given much space and detail, including the structure of the state, the military and the social life of the Hun/Turks, and their impact in Europe when they established a state. Then, the text follows with a detailed introduction of the 
38 - Veysel APAYDIN - Development and Re-Configuration of Heritage...

other early Turkish states that were established from East Asia to Europe in chronological order, with strong implications of nationalistic values and Pan-Turkish ideology.

In the $9^{\text {th }}$ level history classes, a strong discourse lies in the texts. It discusses the conversion to Islam by Turks and the first Turkish-Islamic states in history, with great detail and perfect visual examples of the Turkish-Islamic architectural heritage. The chapter begins with a statement from Atatürk, justifying why Turks were right to accept Islam and why Islam was the most suitable religion for the Turks. This statement is supported in the text as well, as the text compares the Turkic belief "Tengri" to Islam:

... both religions Tengri and Islam, are monotheistic ... belief of heaven and hell ... hygiene was very important ... tolerance to other cultures ... theft, lies and injustice were sins ... (Okur et al. 2013: 135).

The curricula and textbooks of all levels do not have any chronological order or structure. In addition to the history of Early Turkish state, the Ottoman Empire and Islam, the history of Turkish Republic with its construction period and the role of Atatürk are the main foci.

All curricula from the 4th to 8th levels and the textbooks from the 9th to 11th levels strongly dictate teachers to emphasise the "unity" of the Turkish state and related national days, which consolidate that unity. For instance, the 5th level curriculum instructs teachers how to start the topic:

...to start a class, write the national and religious feasts that we celebrate throughout the year ... point out the importance of these feasts for our unity ... for instance, give examples of the feast of the sacrifice religious day (one of the religious activity days of Islam) ... (Başol et al. 2013: 102)

Textbooks also use visuals which have nationalistic values. I would also argue that there is a strong imposition of Turkish ideology in the curriculum through the use of images as well. The main reason for imposing specific images of places and monuments is that spaces and monuments have a significant role in forming 
the minds of every individual (Rüsen 1994; Behre and Arne 1985). The monumental structures of the national, Ottoman and Islamic periods are emphasised by the authors because they want students to realise and make connections between the past, present and future, and therefore construct the historical consciousness through interpreting past monuments, which will shape their understanding of the present and also future expectations (see Rüsen 1994; Behre and Arne 1985).

After having years of formal education from an official and nationalist perspective, which neglects other cultures' pasts, people see, think and evaluate the past as they are instructed during the schooling process. For instance, local community members, who live near Çatalhöyük, a UNESCO world heritage site, explained their understanding of past and heritage:

... the past and values of the Turks, Ottoman and Islam are very significant for us. If they did not fight for our lands and protect our identity and religion we wouldn't be here now. However, archaeological sites such as Çatalhöyük are far from us because they are not from our past and culture ... (male 2103).

... our own past began with the arrival of Islam and became very glorious with the success of the Turks and Ottomans ... Çatalhöyük has no connection with Islamic periods; therefore, it does not have any importance for myself ... (male 2013).

These anecdotes illustrate some of the ideological aspects that have been passed on by the Turkish state to its citizens through education. These interviewed community members' heritage perceptions have been formed by textbooks and their comments reflect these school textbooks, where specific information is imposed. Although Çatalhöyük is a site that has international significance for the human past, they don't see it as 'their' heritage; the histories of other cultures are not mentioned at all (see Apaydin 2016), and they only see heritage as Turkish, Islamic and Ottoman.

Although I certainly advocate that the Islamic, Ottoman and Turkish pasts, and related cultural heritage elements, must be taught 
40 - Veysel APAYDIN - Development and Re-Configuration of Heritage...

to children in order to increase heritage awareness, other cultural heritage elements of the minorities, such as Greek, Arabic and Kurdish, should be also taught to children. Learning about other cultures can prevent the neglect of and increase the protection and preservation of other heritage sites that are not related to the Turkish national past.

The main reason for not teaching about other cultures is so as not to break the idea of a continuous Turkish past in Turkey, as Copeaux (2003) points out. If the textbooks discuss the pasts of Greeks or Armenians as part of Turkey's past, it could contradict the Turkish ideology that does not recognise the existence of these two ethnic minorities in this land but argues that the oldest and most developed civilization has always been the Turks. However, the curriculum also contradicts itself as sometimes these two minorities are shown as enemies, which means that their existence is reluctantly accepted (Copeaux 2003).

\section{Minority Past and Heritage: The Others}

The minorities I refer to here encompass both ethnic and religious groups who have different cultural values from the majority of the population who have the ruling power the country. The reason for the existence and the idea of being a nation state do not promote diversity, but rather homogenise society in order to survive (Levene 2000: 21). On one hand, the UN 1948 Human Rights Declaration clearly points to the protection of cultural practices of individuals and groups (Silverman and Ruggles 2007: 4); on the other hand, there are many examples of the violation of minority rights, which can be seen in many nation states (Medda-Windischer 2003). It is perhaps because of the idea of being a nation that the nation state overrides the rights of minorities and their cultural heritage; it is the first step of nation states to deny the existence of minorities. Turkey is one of those nation states that tried to homogenise the country (see Akçam 2008; Akdar 2000).

The area where the Turkish nation state was founded was very ethno-culturally rich. Though because of assimilation and forced deportation policies the number of those ethnic and religious groups 
is not clearly known, some general data still exists and the nature of these groups can be identified (for more detail, see KizilkanKisacik 2013; MGIR 2007; Karimova and Deverell 2001).

Therefore, Turkey has various minority groups who have tangible and intangible heritage all around Turkey. However, the contents of textbooks and curricula don't even mention the pasts of these groups and don't present their heritage to students. Instead, minorities, such as the Greeks and Armenians, are presented in textbooks as the Other and they are always portrayed as traitors. For instance, the $8^{\text {th }}$ level history textbook emphasises:

... teach students that the Greek and Armenian citizens of the Ottoman Empire supported the coalition forces' occupation (Başol et al. 2013: 99).

The otherness has always been given great importance in teaching the history of Turkey (Copeaux 1998b). The main reason for this is that if society is established based on a certain ethnic group identity, in this case Turkish ethnicity, it needs to create the 'others' in order to justify its existence and identity (Tekeli 1998: 2). One of the most striking parts of the textbooks is found in the $8^{\text {th }}$ level, in a section called "Threats to Turkey" (see Başol et al 2013: 274), which contains discourses about Armenians and present them as enemies. For instance:

... Armenians were affected by nationalism and with the provocation of other countries Armenians rose up against the state and they damaged the state in many ways. As a result of this uprising the state had to make a decree about "expulsion and resettling" for Armenians ... (Başol et al. 2013: 276).

In the $10^{\text {th }}$ level history textbooks, strong discourses and manipulations continue about Armenians. The Armenians are always presented as killers and murderers of Turks; the Armenians also rose up, provoked by the Russians:

... Armenians were quite rich as they were craftsmen and bankers ... the population of Armenians was never more than $20 \%$ even in the most populated areas ... they 
42 - Veysel APAYDIN - Development and Re-Configuration of Heritage...

claimed the east of Anatolia to establish an Armenian state ... (Turan et al. 2013: 188-189).

Most of the interview participants from Ani, which is a site that contains mostly Armenian heritage but is surrounded mainly by Turkish communities today, interpreted the Armenians as enemies who aimed take the lands of Turkey. For instance, the local community members point out:

Armenians always want to take our lands as happened in 1918. However, our grandfathers fought against them and died in order not to give away our lands ... the architectural buildings of Ani are mostly Turkish and Islamic, therefore, Ani is our heritage... (male 2013).

The Armenians aim to get strong in the region and take our lands. We would never allow such attempts in the region.... (male 2013).

Therefore, subjective or one-sided teaching of the past deprives students of developing critical thinking about past events. As a result, students develop a historical consciousness through creating 'otherness' and hatred against certain groups, which without doubt affects the perception of heritage, as demonstrated by the case of interview participants in Ani (see Apaydin 2015).

History textbooks have always been used for hate campaigns against certain groups and for creating otherness (see Stobart 1999; Pingel 1999; Bourdillion 1994). The main reason for discussing the Armenian community here is to present how the Turkish state develops a perception in the students' minds by imposing certain aspects and manipulative elements to develop prejudice in students against specific ethnic groups. As a result of this intense and onesided and manipulative education from early ages to adulthood, many people develop a neglect towards heritage and past materials which are not from the national past. 


\section{Prehistoric and Ancient Pasts, and Antiquities}

Teaching of the prehistoric and ancient pasts, and antiquities begins in the $6^{\text {th }}$ level. However, the time allocation is limited to two hours and content is very restricted; in comparison with the national past it has very small place in the textbooks. The thousands of years of Palaeolithic and Neolithic periods are discussed in only a few paragraphs (see Köstüklü 2013: 82-84). The following section in the $6^{\text {th }}$ level is allotted to 'the cradle of civilisations' and mentions the civilisations of Mesopotamia and Anatolia from $4000 \mathrm{BC}$ to the end of first millennium BC with only five hours in total.

Most of the section is devoted to the social, cultural and political life of the Sumerians and Hittites. During the first decades of the Republic, nationalists aimed to make connections with early civilisations in order to claim the lands and ownership rights of Anatolia (Apaydin 2015). Although the texts do not indicate any connection between Turks and Hittites and Sumerians directly, the importance of Sumerian and Hittites is still covered in the history textbooks, as in the earlier textbooks (see Copeaux 2003).

The section has strong manipulative discourses, and aspects of perception management in the text can be seen in the fact that the ancient Greek civilisation is not reflected at all. Instead of using the term 'Greek', 'Ionian' is used instead to describe the culture or civilisations; the use of the word 'Greek' is avoided with care. However, Ionians, who were Greeks, established many cities and used to dominate almost the whole of west Turkey in the first millennium BC (Kenneth 2011; Kenneth-Sams 2011). Although the texts of this section mentions Greek cities such as Miletus and Ephesus, and important figures such as Thales, Herodotus and Hippocrates and the gods and goddess of Greek mythology, the Greeks are referred to as Ionians:

... to start this subject, give insights about Ionians [in the west of Turkey] and their social and political structures, their contribution to humanity ... what those contributions were ... (Köstüklü 2013: 92).

This manipulation and perception management goes back to the first decades of the Republic, during the construction of the 
official history thesis (see Apaydin 2015; Ersanlı 2003). Therefore, in the history books, an Ionian identity is constructed in order to manipulate Greek identity and its past in Turkey, although the Ionians were also part of Greek culture (Copeaux 1998b: 82).

The $7^{\text {th }}$ level curricula instruct teachers to discuss technological innovations of the past very briefly (see Güven 2013: 154). The $8^{\text {th }}$ level doesn't have any content related to the prehistoric and ancient pasts, and material culture. The $9^{\text {th }}$ level history textbook begins with introducing the history of science, history writing and general information on the other subjects such as geography, archaeology, etc (see Okur et al. 2013). However, archaeology is discussed in only a few sentences and the text does not have a detail information about archaeology as a social science (Okur et al. 2013: 26). Although the text talks about archaeology and archaeological data from the sites, it does not explain how archaeology works or how and why excavation finds are taken museums, analysed and displayed for the public.

The Palaeolithic and Neolithic periods are covered again in the $9^{\text {th }}$ level, but only very briefly with couple of paragraphs on the famous Palaeolithic sites in Turkey and France, such as Karain Cave in Turkey and the Lascaux wall paintings in France. The second chapter of the $9^{\text {th }}$ level schoolbook is called 'The Birth of Civilisation and the First Civilisations'. In the first part, the prehistoric periods are described very briefly, with a couple of examples, mainly from Turkey. The second part of this chapter begins with a little information on the civilisations in Mesopotamia, such as Sumerians and Assyrians, and then follows with the early civilisations in Central Asia, Egypt, Persia, Indian, China, Phoenicia, and the Hebrews; then it begins to examine the early civilisations of Anatolia.

The text of $9^{\text {th }}$ level also gives the social, economic and political structures of the early civilisations of Anatolia in chronological order by introducing Hittites, Urartu, Phrygia, Ionians, Aegean and Greeks (from the mainland of Greece), and the Roman Empire. The tens of thousands of years of prehistory are introduced to students in only two or three paragraphs and the time and place allotted very limited. As a result of this lack of information about prehistoric periods in the textbooks, individuals have grown up with very limited knowledge, 
and therefore their neglect of prehistoric sites increases. In the case of Çatalhöyük, many community members indicated their lack of information about Çatalhöyük; this is one of the reasons for not considering Çatalhöyük as a heritage site (see Apaydin 2016).

\section{Conclusion}

I have examined the nationalistic and religious aspects; how minorities and their histories are presented; and the presentation of the prehistoric and ancient pasts in the history curricula and textbooks in Turkish formal education. As can be seen from the contents of the curricula and textbooks, and the numerical analyses of the contents, information on the national past, which includes Turkish, Ottoman and Islamic history, is prominently presented in almost all levels of formal education. These elements are presented and documented in detailed and specific ways in order to develop the ideological heritage perceptions of students.

The first way or method used is that in almost all levels' accounts there are hidden discourses intended to form and influence the students' views. This is to make students believe that the earliest civilizations were established in central Asia by Turks, and that it was right to convert to Islam. This is accomplished by making a connection between the modern day Turkey and early civilizations. Making further connections between the early Turks' belief system and Islam is intended make students think that is why it was the right decision to convert to Islam.

The second method is that the texts contain a high level of hate and discriminatory discourses, as in the case of the Armenians. The third method is the use of media. I have pointed out above the importance of locations and monuments for developing the perception of students. In almost all the levels, the textbooks and curricula contain pictures of monuments and places, which are significant for Turkish and Islamic history, on every single page.

The history of present day minorities in Turkey is completely disregarded. Throughout all the levels of the textbooks and curricula, only two paragraphs mention other ethnic groups, and furthermore 
46 - Veysel APAYDIN - Development and Re-Configuration of Heritage...

only mention their names without providing background information about their cultures and socio-political structures. Instead, as in the case of Greeks and Armenians, they are presented as the enemies of the Turks across the texts.

The prehistoric and ancient pasts are given a very insignificant place in the textbooks. The complete human history of Anatolia and nearby regions, such as the east Mediterranean, the Middle East or the Central Asia, is presented to students in only a few pages. The prehistoric past of Europe, the Americas and Africa are neglected in the textbooks. As a result of teaching discriminative and hate discourses about minorities and lack of information about human history, prehistory and antiquities, students are growing up without any ability to develop wider heritage perceptions and awareness about the past and past cultures.

\section{Acknowledgements}

The author wishes to thank community members who live nearby the archaeological and heritage sites, Çatalhöyük and Ani, for taking part in this research.

\section{Note on Contributor}

Veysel Apaydin completed his PhD at the Institute of Archaeology, University College London. His doctoral thesis (2015) evaluated political use of the past, identity construction and the relationship between heritage, education and attitudes towards heritage, taking modern-day Turkey as its case study.

\section{Bibliography}

Akçam, T. 2004. From Empire to Republic. Turkish Nationalism and the Armenian Genocide. London and New York: Zed Books.

Akçam, T. 2008. Ermeni Meselesi Hallolunmustur. Osmanlı Belgelerine Göre Savaş Yıllarında Ermenilere Yönelik Politikalar. Istanbul: Iletişim Yayınları

Akdar, A. 2000. Varlık Vergisi Ve Türkleştirme Politikaları. Istanbul: Iletişim Yayınları. 
Veysel APAYDIN - Development and Re-Configuration of Heritage.. - 47

Apaydin, V. 2015. The Presentation of the Past: Pitfalls and Potentials-education and Archaeology, Heritage and Communities in Turkey-The Case Studies of Çatalhöyük, Ani and Hattuşa. Unpublished PhD thesis. University College London.

Apaydin, V. 2016. Effective or not? Success or failure? Assessing heritage and archaeological education programmes - the case of Çatalhöyük. International Journal of Heritage Studies, DOI:10.1 080/13527258.2016.1218912

Apple, M. W. 2009. Ideology and Curriculum. New York: Routledge. Atakuman, C. 2008. Cradle or crucible: Anatolia and Archaeology in the early years of the Turkish Republic (1923-1938). Journal of Social Archaeology 8, 214-235.

Behre,G.andLars,A.1985.Geschihtsdidaktik, Geschichtswissenschaft, Gesellschaft. Stockholm: Liber Tyrick AB.

Başol, S., Ünal, F., Azer, H., Yıldız, A. and Evirgen, O. F. 2013. Ilkögretim Sosyal Bilgiler Ögretmen Kılavuz Kitabı 5 (Primary Education social sciences curricula for 5th level). MEB: Milli Eğitim Bakanliği Yayınları.

Başol, S., Yildirim, T., Koyuncu, M., Yildiz, A., and Evirgen O.F. 2013. Inkilap Tarihi ve Ataturkculuk. Ogretmen Kılavuz Kitabı 8 (Primary Education Curricula for 8th level). MEB: Milli Eğitim Bakanliği Yayınları.

Bourdillion, H. (ed). 1994. Teaching History. The Open History. London: Routledge.

Copeaux, E. 1998a. Tarih Ders Kitaplarında (1931-1993): Türk Tarih Tezinden Türk Islam Sentezine. Istanbul: Tarih Vakfı Yurt Yayınları.

Copeaux, E. 1998b. Turkiye'de Kimlik Soyleminin Topografyasi ve Kronografisi. In Tarih Eğitimi ve Öteki Sorunu. 2. Uluslararasi Tarih Kongresi. 8-10 Haziran 1995 Istanbul. Istanbul: Tarih Vakfı Yurt Yayınları, 70-85.

Copeaux, E. 2003. Turkiye'de 1931-1993 Arasinda Tarih Ders Kitaplari. In Köymen, O. (ed) Tarih Eğitimine Eleştirel Yaklaşımlar. Istanbul: Turkiye Ekonomik ve Toplumsal Tarih Vakfı, 107-113.

Corbishley, M. 2004. English Heritage Education: Learning to Learn From the Past. In Henson, D. et al. (eds). Education and Historic Environment. London: Routledge, 67-73.

Corbishley, M. 2011. Pinning Down the Past. Archaeology, Heritage, and Education Today. Woodbridge: The Boydell Press. 
48 - Veysel APAYDIN - Development and Re-Configuration of Heritage...

Doughty, L. 2007. National Curricula and the Politics of Archaeology. The Turkish Case. In Hodder, I. and Doughty, L. (eds) Mediterranean Prehistoric Heritage. Training, Education and Management. Mcdonald Institute for Archaeological Research. Cambridge: University of Cambridge, 138-40.

Ersanlı, B. 2003. Iktidar ve Tarih. Türkiye'de "Resmi Tarih" Tezinin Oluşumu (1929-1937). Istanbul: Iletişim Yayınları.

Fairclough, N. L. and Wodak, R. 1997. Critical discourse analysis. In T. A. van Dijk (ed.), Discourse Studies. A Multidisciplinary Introduction, Vol. 2. Discourse as Social Interaction. London: Sage, 258-84.

Guler-Biyiklı, S. and Aslan, C. 2013. A Review of Cultural Heritage Education in Turkish Schools (1962-2011). Public Archaeology, Vol. 12, No. 4, 255-70.

Günaltay, S. 1939. Atatürk'ün Tarihçiliği ve Fahri Profesörlüğü Hakkında bir Hatıra. Belleten III, 10, 273-274.

Güven, I. (eds) 2013. Ilköğretim Sosyal Bigiler Ögretmen Kılavuz Kitabı 7 (Primary Education Soscial Sciences Curricula for 7th level) MEB: Milli Eğitim Bakanlığı Yayınları.

Kaplan, I. 1999. Türkiye'de Milli Eğitim Ideolojisi. Istanbul: Iletişim Yayınları.

Karimova, N. and Deverell, E. 2001. Minorities in Turkey. Stockholm: Utrikespolitiska Institutet The Swedish Institute of International Affairs.

Kasvikis, K., Vella, N. and Doughty 2007. National Curricula and the Politics of Archaeology. In Hodder, I. and Doughty, L. (eds) Mediterranean Prehistoric Heritage. Training, Education and Management. Mcdonald Institute for Archaeological Research. Cambridge: University of Cambridge, 129-145.

Kenneth W. H. 2011. The Greeks in Anatolia: From the Migrations to Alexander the Great. In MacMahon, G and Steadman, S. (eds) The Oxford Handbook of Ancient Anatolia (10, 000-323 BCE). Oxford: Oxford University Press, 752-776.

Kenneth-Sams, G. 2011. Anatolia: The First Millenium B.C.E. in Historical Context. In Mcmahon, G. and Sharon, S. (eds) The Oxford Handbook of 438 Ancient Anatolia: (10,000-323 BCE). Oxfod: Oxford University Press, 604-622.

Kizilkan-Kisacik, Z. B. 2013. Europeanization of Minority Norms in Turkey. Baden: Nomos. Baden-Baden 214. 
Kaya-Koyuncu, M., Dağ, O., Koçak, E., Yıldırım, T. 2013. Sosyal Bilgiler Ogretmen Kılavuz Kitabi 4 (Soscial sciencies curricula for 4th level). MEB: Milli Eğitim Bakanlığı Yayınları.

Köstüklü, N. (eds) 2013. Ilkögretim Sosyal Bilgiler Ögretmen Kılavuz Kitabı 6 (Primary Education Soscial Sciences Curricula for 6th level). MEB: Milli Eğitim Bakanlığı Yayınları.

Levene, M. 2000. The Limits of Tolerance: Nation-State Building and What It Means for Minority Groups. Patterns of Prejudice, 34: 2, 19-40.

Medda-Windischer, R. 2003. The European Court of Human Rights and Minority Rights. European Integration, Vol. 25-3, 249-271.

Minority Groups International Report (MGIR) 2007. A Quest for Equality: Minorities in Turkey. London: MRG.

Okur, Y., Genç, I., Özcan, T., Yurtbay, M. and Sever, A. 2013. Ortaöğretim TARIH 9 (History 9th level). MEB: Milli Eğitim Bakanlığı Yayınları.

Pingel, F. 1999. Unesco Guidebook on Textbook Research and Textbook Revision. George Eckert Institute for International Textbook Research, UNESCO.

Roord 2004. Heritage and History Education at Schools. In the Hague Forum 2004. Heritage and Education: A European Perspective. From WWW [http://www.europanostra.org/UPLOADS/FILS/forum_ heritage_education_proceedings.pdf] (Accessed in 01.12.2015)

Rüsen, J. 1994. Historische Orienterung. Über die Arbeit des Geschichtsbewußtseins, sich in der Zeit Zurechtzufinden. Köln: Böhlau.

Silverman, H. and Ruggles, D. F. 2007. Cultural Heritage and Human Rights. In Silverman, H. and Ruggles, F. D. (eds) Cultural Heritage and Human Rights. New York: Springer, 3-22.

Smith, A. D. 1994. Gastronomy or geology? The role of nationalism in the reconstruction of nations. Nations and Nationalism No 1 , 18.

Stobart, M. 1999. Fifty Years of European Co-Operation on History Textbooks: The Role and Contribution of the Council of Europe. International Textbook Research. Vol. 21, No: 2, 147-161.

Stone, P. G. 1985. Education-an opportunity and an obligation? Rescue News 37: 2, 10-15.

Stone, P.G. and Molyneaux, B. L. (eds) 1994. The Presented Past. Heritage, Museums and Education. London, New York: Routledge in association with English Heritage. 
50 - Veysel APAYDIN - Development and Re-Configuration of Heritage...

Tarman, B. 2008. The European Union And The Modernization of The Turkish Education System. Amherst, New York: Cambria Press.

Tekeli, I. 1998. Tarih Yazıcılığı ve Öteki Kavramı Üzerine Düşünceler. In Tarih Eğitimi ve Öteki Sorunu. 2. Uluslararası Tarih Kongresi. 8-10 Haziran 1995 Istanbul. Istanbul: Tarih Vakfı Yurt Yayınları, 1-7.

Turan, V., Genç, I., Çelik, M., Genç, C. and Turedi, S. 2013. Örtaöğretim TARIH 10 (History 10th level). MEB: Milli Eğitim Bakanlığı Yayınları.

UNESCO 1972. Recommendation concerning the Protection, at National Level, of the Cultural and Natural Heritage. Educational and Cultural Actions, Article 61. From WWW [http://portal.unesco. org/en/ev.php URL_ID $=13087 \& U R L$ DO =DO_TOPIC\&URL_ SECTION=201.html] (Accessed in 15.12.2015). 